\title{
DEFINITION OF MAMMARY EUTROPHY FOR WOMEN IN THE MENACME
}

\author{
Angelo do Carmo Silva Matthes ${ }^{1}$
} Renata Barrenha Sgrignoli²

Matthes ACS, Sgrignoli RB. Definition of mammary eutrophy for women in the menacme. Rev Latino-am Enfermagem 2009 janeiro-fevereiro; 17(1):108-112.

The definition of normal breasts is not well established yet. This study aimed to identify this condition using anthropometric measures, correlating them with the subjective evaluation of satisfaction or dissatisfaction. Normal breasts are assumed to be breasts of women who consider themselves satisfied with their breasts. Data were collected through interviews with 255 women who had anthropometric measures taken from their breasts. Subjects were divided into two groups, 146 (57\%) women were satisfied and 109 (42.7\%) dissatisfied. Of these, $66 \%$ had a negative nipple-to-inframammary fold distance (AM section) and, in $73 \%$ of patients, the distance from the sternal manubrium to the nipple (FM section) was greater than $24 \mathrm{~cm}$. Among satisfied subjects, $84 \%$ had angles (arm-thorax opening) of less than or equal to 90ú. It was concluded that the best parameters to define breast normality, based on the degree of satisfaction, is FM measure shorter than $25 \mathrm{~cm}$, positive AM measure and a maximum $90 u$ arm angle.

DESCRIPTORS: breast; personal satisfaction; body image

\section{DEFINICIÓN DE SENOS NORMALES PARA MUJERES EN MENACME}

La definición de senos normales todavía no está bien establecida; este presente estudio tuvo como objetivo definirla a partir de medidas antropométricas, correlacionando esas medidas con la evaluación subjetiva de la satisfacción de las mujeres; así, los senos normales serían de aquellas mujeres que se consideran satisfechas. Se utilizó un cuestionario construido por las autoras para entrevistar a 255 mujeres. Se formaron dos grupos: uno de 146 (57\%) satisfechas y otro de 109 (42.7\%) insatisfechas. Entre estas, (66\%) la distancia del pezón al pliegue inframamario (segmento $A M$ ) tenía un valor negativo y la distancia de la fúrcula esternal al pezón (segmento FM) fue superior a 24 centímetros. El ángulo (abertura del brazo en relación al tórax) era inferior o igual a 90ú, y correspondió a $84 \%$ de las mujeres satisfechas. Se concluyó que los mejores parámetros para definir la normalidad del seno, basados en el grado de satisfacción, son: la medida FM menor que $25 \mathrm{~cm} .$, la medida AM positiva y el ángulo del brazo con un máximo de 900.

DESCRIPTORES: mama; satisfacción personal; imagen corporal

\section{DEFINIÇÃO DE EUTROFIA MAMÁRIA PARA MULHERES NA MENACMA}

A definição de mamas normais ainda não está bem estabelecida e este estudo teve como objetivo defini-las como tal, a partir de medidas antropométricas, correlacionando-as com a avaliação subjetiva de satisfação ou insatisfação; sendo que mamas normais seriam aquelas de mulheres que se consideram satisfeitas. Foram entrevistadas 225 mulheres que tiveram medidas antropométricas realizadas em suas mamas. Formou-se dois grupos: 146 (57\%) de satisfeitas e 109 (42,7\%) de insatisfeitas. Dessas, 66\% tinham a distância do mamilo à prega inframamária (segmento $A M$ ) com valor negativo e a distância da fúrcula esternal ao mamilo (segmento FM) foi superior a $24 \mathrm{~cm}$ em $73 \%$. O ângulo (abertura do braço em relação ao tórax) inferior ou igual a $90 u$ correspondeu a $84 \%$ das satisfeitas. Concluiu-se que os melhores parâmetros para definir normalidade da mama, baseados no grau de satisfação, é a medida $F M$ menor que $25 \mathrm{~cm}$, medida AM positiva e o ângulo do braço no máximo de 900.

DESCRITORES: mama; satisfação pessoal; imagem corporal

Faculdade de Medicina do Centro Universitário Barão de Mauá, Brazil: ${ }^{1}$ Ph.D. in Medicine, Full Professor, e-mail: matthes@mulheresaude.med.br; ${ }^{2}$ Undergraduate student in Medicine, Scholarship holder, Scientific Initiation Project (PIC) 


\section{INTRODUCTION}

Breasts represent women's femaleness. Any alteration on them modifies their self-esteem and changes the profile women have of their bodies. The lack or loss of parts of the breast cause psycho-social disorders that worsen quality of life of these women ${ }^{(1)}$.

Mastectomy is one of the treatments most women with breast cancer are subject to. Results can lead to physical, emotional and social impairment. The resulting mutilation favors the appearance of several issues in women's life, especially related to body image. Women's perception of this new image and how it affects their life concern professionals who intend to provide comprehensive care ${ }^{(2)}$. Oftentimes, professionals do not understand that women's body image, built throughout their life, is already distorted by the shape, size and asymmetry caused by its abnormal development, causing great suffering and actual illness.

The World Health Organization (WHO) defines health as a state of physical, mental and social wellbeing and not the absence of disease ${ }^{(3)}$.

Women who suffer for having big or very small breasts certainly are not healthy according to the WHO concept and need care to develop health. It is worth reminding that, in ICD-10, International Classification of Diseases, ICDs N64.2 and N62 classify breast atrophy and hypertrophy, respectively, grouped under the disorders of breast ${ }^{(4)}$ subgroup. Paradoxically, there are health insurance reviewers who do not consider them as diseases and classify surgical correction as aesthetic $^{(5)}$ and not repairing ${ }^{(6)}$ procedures.

In some situations, women do not have developed breasts due to genetic alterations, such as Polland's syndrome, or due to hormonal alterations. The absence of breasts or the presence of rudimentary teats subject them to unpleasant nicknames, which certainly enables the development of low self-esteem and distortion of their body image, meaning that they are not healthy. These women need professional health care and deserve repair of their breasts, through prosthesis implantation to increase breasts or correct symmetry $^{(7)}$.

In current literature, there are no parameters to define what a normal or altered breast is. But what is actually a normal breast?

The answer is in the patient itself. Women who are satisfied with their breasts, without low self-esteem or psychosocial alteration, have normal breasts, regardless of shape, volume or position of nipple-areola complex ${ }^{(8)}$. All other women who have breast health problems consider their breasts abnormal and need breast reconstruction to rescue their self-esteem ${ }^{(9)}$. It is important to identify breasts that make patients satisfied and thus define them as normal teats, in order to have a scientific basis to help patients dissatisfied with their breasts. Characterization and development of policies for breast plastic surgeries are needed to remedy the unfairness that many women who need breast surgeries are subject to. As some truly repairing surgeries are called aesthetic, and are thus excluded from health plans and the Single Health System (SUS), patients who need them are not entitled to because they are not covered by women's health care services ${ }^{(10)}$.

\section{OBJECTIVE}

To verify which breast anthropometric measures bring more satisfaction to most women, defining a normality pattern to justify, before the SUS and health plans, the need for corrective surgery to patients dissatisfied with their breasts, so as to improve their quality of life and provide health.

\section{CASUISTRY AND METHODS}

The Research Project was approved by Centro Universitário Barão de Mauá Ethics Committee, under registration number 113/2005.

Patients: from November 2005 to August 2006, interviews were held with 255 women, after signing a post-informed consent term, attended in all sectors of Centro Universitário Barão de Mauá (CBM), between 20 and 50 years old and in the menacme.

Inclusion criteria: women in the menacme over 18 and under 50 years old and without previous breast surgeries.

Method: women were contacted at CBM and informed about the research. After signing postinformed consent, they answered a questionnaire developed by the authors, containing information regarding age, parity, lactation condition and subjective evaluation of satisfaction or dissatisfaction with breasts.

Women were subject to examination by an examiner in a previously selected room at CBM, standing and with arms parallel to the thorax. Using a tape measure, the examiner registered the following 
measures on a form: FM - distance from the sternal manubrium to the nipple, $A M$ - distance from point $A$ to point $M$. Point $A$ is the intersection of an imaginary line starting at the center of the clavicle, passing through the breast and inframammary fold vertexes, and forming the AM section. It measures $0 \mathrm{~cm}$ when point $A$ superposes point $M^{(11-13)}$, and is positive if point $M$ is above point $A$ and negative if below, as verified in ordinate and abscissa measuring.

Arm angle in relation to thorax (Figure 1) was also investigated. A pencil was placed on the inframammary fold and the patient was asked to raise her arms, thus forming an angle with the body that varied from $0^{\circ}$, when arms were down, to $180^{\circ}$ when the arms were above the thorax, parallel to patients' head.

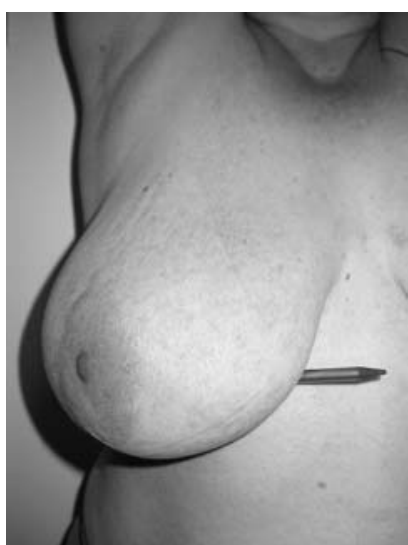

Figure 1 - Arm angle in relation to thorax. When arm is totally raised forming a $180^{\circ}$ angle, breast 'holds' pencil in the inframammary fold

\section{STATISTICALANALYSIS}

Data were statistically analyzed using the chisquare test and GraphPad and Prism data computing systems. Version 5.3 (R2006b) Statistics Toolbox Software was used for inferential statistical analysis of results. Analysis of variance was applied to measure the effect of independent variables. ANOVA was applied when conditions of normal data distribution independence of data and homogeneity of variance were met. In other cases, the Kruskal-Wallis test was applied, with significant results.

\section{RESULTS}

Among the 255 women examined, 146 (57\%) were satisfied with their breasts, 130 (89\%) of whom were very satisfied and only $16(11 \%)$ little satisfied;
109 (43\%) were dissatisfied, 62 (57\%) of whom had small breasts and 47 (43\%) big breasts, representing almost $20 \%$ of the studied population. Age varied from 18 to 50 years and all were in the menacme. Satisfaction with breasts in relation to age is shown in Table 1.

Table 1 - Distribution of patients according to age and satisfaction with breasts, if small or big

\begin{tabular}{ccccc}
\hline \multirow{2}{*}{ Age } & Satisfied & \multicolumn{2}{c}{ Dissatisfied } & Total \\
& & Small & Big & \\
\hline$<20$ & 28 & 23 & 0 & 51 \\
$21-30$ & 68 & 31 & 15 & 114 \\
$31-40$ & 20 & 5 & 15 & 40 \\
$41-50$ & 26 & 3 & 17 & 46 \\
SR $^{*}$ & 4 & 0 & 0 & 4 \\
Total & 146 & 62 & 47 & 255 \\
\hline * NR - no records & & & &
\end{tabular}

Table 2 shows distribution of patients according to satisfaction with sternal manubriumnipple measurement.

Table 2 - Distribution of patients according to satisfaction with sternal manubrium-nipple measurement (FM)

\begin{tabular}{ccccc}
\hline \multirow{2}{*}{ FM $^{*}$} & Satisfied & \multicolumn{2}{c}{ Dissatisfied } & Total \\
& & Small & Big & \\
\hline $15-20$ & 62 & 39 & 1 & 102 \\
$21-25$ & 75 & 21 & 28 & 124 \\
$26-30$ & 7 & 0 & 15 & 22 \\
$>30$ & 2 & 0 & 5 & 7 \\
Total & 146 & 60 & 49 & 255 \\
\hline
\end{tabular}

* FM - distance from the sternal manubrium to the nipple

Table 3 shows the distribution of patients according to satisfaction with measurement from point A to point $M$.

Table 3 - Distribution of patients according to satisfaction with measurement from point $A$ to point M (AM)

\begin{tabular}{lcccc}
\hline \multirow{2}{*}{ AM $^{*}$} & Satisfied & \multicolumn{2}{c}{ Dissatisfied } & Total \\
& & Small & Big & \\
\hline Positive $^{* *}$ & 112 & 57 & 13 & 182 \\
Negative & 33 & 3 & 25 & 61 \\
NR $^{* * *}$ & 1 & 2 & 9 & 12 \\
Total & 146 & 62 & 47 & 255 \\
\hline
\end{tabular}

* AM - distance from the nipple to the inframammary fold

${ }^{* *}$ AM section equaling 0 was considered as positive

NR - no records 
Distribution of patients according to satisfaction with arm opening angle in relation to body while breast holds a pencil is shown in Table 4 .

Table 4 - Distribution of patients according to satisfaction with arm opening angle in relation to body, while breast holds a pencil

\begin{tabular}{ccccc}
\hline \multirow{2}{*}{ Angle $^{*}$} & \multirow{2}{*}{ Satisfied } & \multicolumn{2}{c}{ Dissatisfied } & Total \\
& & Small & Big & \\
\hline $0^{\circ}$ & 94 & 48 & 0 & 142 \\
$<=90^{\circ}$ & 28 & 6 & 3 & 37 \\
$>90^{\circ}$ & 23 & 6 & 44 & 73 \\
$\mathrm{SR}^{* *}$ & 1 & 2 & 0 & 3 \\
Total & 146 & 62 & 47 & 255 \\
\hline
\end{tabular}

${ }^{*}$ Angle - arm opening angle in relation to body while breast holds a pencil NR - no records

\section{DISCUSSION}

Two groups of patients were formed after tabulation of patients' records, one satisfied and the other dissatisfied with their breasts. Dissatisfied patients were then divided into two groups, one for having small and the other big, fallen or asymmetric breasts.

Among the 255 women, 146 (57\%) were satisfied with their breasts, 130 (89\%) of whom very satisfied and only $16(11 \%)$ little satisfied; 109 (43\%) were dissatisfied, $62(57 \%)$ of whom had small breasts and $47(43 \%)$ big breasts, representing almost 20\% of the studied population. Generalizing to the female population, approximately $20 \%$ of women would be impaired in their activities due to dissatisfaction with their breasts, which can represent loss of professional performance and health.

According to Table 1, patients under 30 years of age corresponded to $65 \%$ (165) of studied sample and $66 \%$ (96) of satisfied patients. Analyzing patients up to 40 years, $80 \%$ (116) of satisfied patients are in this age group, showing that age per se is a factor of discontentment with breasts, probably due to anatomic alterations caused by the natural aging process. Nevertheless, breasts' intrinsic condition is equally important and independent of age, considering that, among dissatisfied patients, $80 \%$ (89) were also under 41 years. Among those, 54 (50\%), were younger than 31 years, corresponding to $87 \%$ (54) of patients dissatisfied with having small breasts and 47 (43\%) dissatisfied due to big breasts. Among patients dissatisfied with having big breasts, 32 (68\%) were older than 30 years, which permits infering that satisfaction with breasts depends on age and intrinsic factors, as satisfied patients are equally distributed (58\% and 53\%) in age groups under and over 30 years, respectively. Younger patients, under 30 years, are dissatisfied with having small breasts, while the ones over 30 years are dissatisfied with having big breasts, probably due to parity and lactation.

Regarding FM measure, shown in Table 2, $94 \%$ (137) of satisfied patients have a maximum measure of $25 \mathrm{~cm}$, only $7 \%$ (9) over $26 \mathrm{~cm}$, confirming FM measures over $25 \mathrm{~cm}$ as dissatisfying. The finding that $73 \%$ (36 out of 49 ) of all dissatisfied women due to big breasts have FM measure over $24 \mathrm{~cm}$ also supports this statement. Both observations show that, the higher the FM measure, the higher the degree of dissatisfaction, which is an excellent parameter to define breast normality, assuming measures from 21 to $24 \mathrm{~cm}$ as normal ${ }^{(13-14)}$.

Concerning AM measure, shown in Table 3, $77 \%$ (113) of satisfied patients have point $M$ above point $A$, thus having positive AM. It was also verified that $66 \%$ (25 out of 38 ) of patients dissatisfied due to big breasts have a negative AM section, with point $M$ below point $A$. It shows that breasts with a positive AM section are another excellent parameter to define breast normality.

Table 4 shows satisfaction with arm opening angle while breast holds a pencil, indicating that $84 \%$ (122) of satisfied women have an angle under $90^{\circ}$ and $94 \%$ (44) of women with big breasts have an angle over $90^{\circ}$, which permits inferring that arm angle measure is another excellent parameter to define breast normality.

This study showed correlation between breast measure and women's personal satisfaction, differently from other studies ${ }^{(14-19)}$ that took breasts' anthropometric measures but did not correlate them with personal satisfaction. Those studies based results on surgeons' evaluation that defines non-ptotic breasts as aesthetically perfect, in which case no surgical correction is needed.

\section{CONCLUSION}

It was concluded that the best parameters to define mammary eutrophy, based on the degree of satisfaction, are FM measure shorter than $25 \mathrm{~cm}$, positive AM measure and maximum $90^{\circ}$ arm angle. Therefore, eutrophic breasts can be defined according 
to reproducible anthropometric measures, such as FM measure shorter than $25 \mathrm{~cm}$, positive AM measure and maximum $90^{\circ}$ arm angle, which express personal satisfaction and permit selecting women who, in fact, are not healthy due to dissatisfaction with their breasts. These women would benefit from reparatory breast surgery, what is currently difficult to achieve as health plans consider these surgeries as aesthetic and do not cover them in their policies. Health plans exclusively cover surgeries in women who had their breasts mutilated by cancer surgeries, who undoubtedly need it. They overlook and do not know, however, that many women without cancer are not healthy either. Findings shown in this study corroborate works from literature, showing the importance of body image and self-esteem for quality of life $e^{(2,8,16,18)}$.

\section{REFERENCES}

1. Matthes ACS. Cirurgia estética e reparadora das mamas. Centro Médico Notícias 2004 novembro; 210:19.

2. Ferreira MLSM, Mamede MV. Representação do corpo na relação consigo mesma após mastectomia. Rev Latino-am Enfermagem 2003; 11(3):299-304. http://www.scielo.br/ scielo.php?script =sci_arttext\&pid =s 0104 $11692003000300006 \&$ Ing $=$.

3. World Health Organization - WHO. Constitution Basic Documents. Geneve (Suiss): Fifth-first World Heath Assembly; 2006.

4. CID-10 / Classificação Internacional de Doenças. São Paulo: Organização Mundial de Saúde (OMS); Centro Colaborador da OMS da Universidade de São Paulo; 1998.

5. American Society of Plastic, and Reconstructive Surgeons. Procedures in Plastic Surgery. East Algonquin Road: Arlington Heights; 1989.

6. McInnis WD. Cirurgia Plástica da Mama. In: Mitchell GW, Basset LW. Mastologia Prática. Los Angeles: Revinter; 1993. p. 208-32.

7. Pitanguy I, Franco T. As hipomastias e seu tratamento cirúrgico. O Hospital 1967; 72(5):13-34.

8. Courtiss EH, Goldwyn RM. Breast sensation before and after plastic surgery. Plast Reconstr Surg 1976; 58:1.

9. Dartigues L. Etat actuel de la Chirurgie Esthétique Mammaire Med 1928; 38:75.

10. Ferreira MC. Conceituando cirurgia estética e reparadora.
Jornal do CREMESP 2002 maio; 2:3.

11. Bozola AR. Mamaplastia em " $L$ ". In: Ribeiro $L$, editor. Cirurgia Plástica da Mama. Rio de Janeiro: Medsi; 1989. p. 129-83.

12. Berry EP. Geometric planning in reduction mammaplasty. Plast Rec Surg 1968; 42(3):232-6.

13. Strombeck JO. Mammaplasty: report of a new technique based on the two pedicle procedure. $\mathrm{Br}$ J Plast Surg 1960; 13:79-90.

14. Westreich M. Anthropomorphic breast measurement: Results in 50 women with aesthetically perfect breasts and clinical aplication. Plast Reconstr Surg 1997; 100(2):46879.

15. Penn J. Breast reduction. Br J Plast Surg 1955; 7:35762.

16. Smith DJ Jr, Palin WE Jr, Katch VL, Bennett JE. Breast volume and anthropomorphic measurements: Normal values. Plast Reconstr Surg 1986; 78:331-5.

17. Hsia HC, Thomson JG. Differences in breast shape preferences between plastic surgeons and patients seeking breast augmentation. Plast Reconstr Surg 2003; 112:31220.

18. Fabie A, Delay E, Chavoin JP, Soulhiard F, Seguin P. Plastic sugery application in artistic studies of breast cosmetic. Ann Chir Plast Esthet 2006; 51(2):142-50.

19. Mahmoud EO, Hosnia AM, Bothaina A, Mohamed ES. Assessment of the breast volume by a new simple formula. Indian J of Plastic Surgery 2006; 39:13-16. 